\title{
Effects of High-Dose Methadone Maintenance on Cocaine Place Conditioning, Cocaine Self-Administration, and Mu-Opioid Receptor mRNA Expression in the Rat Brain
}

\author{
Francesco Leri*,', Yan Zhou', Benjamin Goddard', Erin Cummins' and Mary Jeanne Kreek ${ }^{2}$ \\ 'Department of Psychology, University of Guelph, Guelph, ON, Canada; '2Laboratory of the Biology of Addictive Diseases, The Rockefeller \\ University, New York, NY, USA
}

\begin{abstract}
Methadone maintenance at appropriate doses can effectively reduce cocaine abuse in heroin-dependent individuals. In the present studies, we investigated the effect of high-dose methadone maintenance cocaine conditioned place preference (CPP) and cocaine intravenous self-administration. Rats implanted with methadone-filled osmotic mini-pumps (20 and $55 \mathrm{mg} / \mathrm{kg} / \mathrm{day}$, SC) and conditioned with cocaine ( 1,5 , and $20 \mathrm{mg} / \mathrm{kg}$, i.p.) did not express cocaine CPP. Similarly, rats implanted with methadone pumps (55 mg/kg/day) after cocaine conditioning $(20 \mathrm{mg} / \mathrm{kg})$ displayed neither spontaneous nor cocaine-precipitated $(20 \mathrm{mg} / \mathrm{kg}$, i.p.) CPP. In contrast, methadone maintenance (30 and $55 \mathrm{mg} / \mathrm{kg} /$ day, SC) did not alter the intravenous self-administration (continuous schedule of reinforcement) of various doses of cocaine $(0.1,0.5$, and $2.0 \mathrm{mg} / \mathrm{kg} / \mathrm{inf})$. To explore neuropharmacological interactions between methadone maintenance and cocaine conditioning, we quantitatively measured mRNA levels of mu-opioid receptor (MOR) and proopiomelanocortin genes 10 days after methadone maintenance. MOR mRNA levels in both the nucleus accumbens core and frontal cortex were significantly elevated in rats exposed to cocaine during CPP conditioning. However, upregulation of MOR mRNA levels in the nucleus accumbens core were reduced by methadone maintenance in a dose-dependent manner. In conclusion, our results suggest that high-dose methadone maintenance does not alter the direct reinforcing effect of cocaine, but blocks spontaneous and cocaine-precipitated cocaine-seeking, possibly by preventing MOR alterations in the nucleus accumbens core induced by cocaine conditioning. Neuropsychopharmacology (2006) 31, |462-1474. doi:I0.1038/sj.npp. I300927; published online 12 October 2005
\end{abstract}

Keywords: methadone; cocaine; mu-opioid receptor; mRNA; hypothalamic-pituitary-adrenal axis; proopiomelanocortin peptide

\section{INTRODUCTION}

Cocaine abuse is commonly observed in individuals enrolled in methadone maintenance programs (Grella et al, 1997; Hartel et al, 1995; Kidorf and Stitzer, 1993; Kosten et al, 1987; Levin et al, 1996; Magura et al, 1998), and it is associated with significant health risks (Foltin and Fischman, 1996) and with negative treatment outcomes, including relapse (Dolan et al, 2001; Kosten et al, 1988; Perez et al, 1997). Contingency management interventions have been found to be efficacious in reducing cocaine abuse (Sigmon et al, 2004), but this approach appears to be effective in about $50-60 \%$ of methadone patients (Silverman et al, 1996). Those who do not profit from cognitive-

*Correspondence: Dr F Leri, Department of Psychology, University of Guelph, Mac Kinnon Building, Guelph, ON, Canada NIG 2WI, Tel: + I 519824 4120×58264, Fax: + I 5198378629 ,

E-mail: fleri@uoguelph.ca

Received 22 May 2005; revised 29 August 2005; accepted 30 August 2005

Online publication: 2 September 2005 at http://www.acnp.org/citations/ Npp09020505034I/default.pdf behavioral interventions may require higher methadone dosages (Stine et al, 1992; Strain et al, 1994).

There is some evidence, in fact, that at appropriate doses, methadone maintenance can decrease cocaine use in heroin-cocaine co-users. In a clinical trial by Strain et al (1993), it was found that rates of cocaine use were lower among patients maintained on $50 \mathrm{mg} /$ day $(52.6 \%)$ compared to those maintained on $20 \mathrm{mg} /$ day $(62.4 \%)$. Similarly, Borg et al (1999) found that $69 \%$ of patients stopped regular cocaine abuse when maintained on average methadone dose of $67.1 \mathrm{mg} /$ day $( \pm 2.1)$. Stine et al (1991) developed a contingency treatment program in which the patient's methadone dose increased by $5 \mathrm{mg}$ in response to each cocaine-positive urine screen, up to a maximum dose of $120 \mathrm{mg} /$ day. Under these conditions, when the methadone dose achieved an average of $115 \mathrm{mg} /$ day, cocaine-positive urine samples decreased by $89.2 \%$. Finally, Schottenfeld et al (2005) recently reported that methadone maintenance (65-85 mg/day), even without formal contingency management, promoted retention in treatment, significantly reduced opioid and cocaine use, and enhanced the length of abstinence from both drugs. 
Higher doses of methadone may be required in patients who display severe cocaine abuse because cocaine exposure can alter mu-opioid receptors in the central nervous system (Azaryan et al, 1996; Yuferov et al, 1999; Unterwald, 2001). In rats, 14 days of binge-pattern cocaine administration increased mu-opioid receptor density in striatal-corticolimbic areas, including the nucleus accumbens and subregions of the frontal cortex (FC) (Unterwald et al, 1992). Using PET technology, upregulation of mu-opioid receptor binding has been observed in cocaine-dependent individuals, and it has been associated with cocaine cravings (Gorelick et al, 2005; Zubieta et al, 1996). Thus, heavy cocaine users may necessitate more aggressive methadone titration to compensate for cocaine-induced upregulation of mu-opioid receptor density in regions of the brain involved in drug-taking and drug-seeking behaviors (Self, 2004).

Paradoxically, pre-clinical studies performed in human subjects have found that methadone maintenance at doses ranging between 50 and $100 \mathrm{mg} /$ day do not modify, and can even enhance, subjective reports of liking and stimulation induced by acute cocaine challenges (Foltin et al, 1995; Foltin and Fischman, 1996; Preston et al, 1996). These results suggest the hypothesis that methadone maintenance, even at high doses, may not alter the direct reinforcing and stimulatory effects of cocaine, but may still reduce cocaine abuse by attenuating cocaine-seeking behavior. In support of this idea, it has been found that methadone maintenance in rats does not reduce the acute stimulatory effect of cocaine on locomotion, but significantly reduces both heroin- and cocaine-seeking behavior, as indexed by rates of lever pressing in extinction conditions (Leri et al, 2004). The interpretation of this latter result, however, is complicated by findings in primates suggesting that chronic methadone exposure has a significant effect on rates of operant responding per se (Negus and Mello, 2004).

Therefore, the present experiments in rats were designed to investigate the effect of high-dose methadone maintenance on cocaine-seeking behavior measured using a procedure that does not rely on operant responding, namely the conditioned place preference (CPP). In the first experiment, rats were maintained on methadone during cocaine conditioning and CPP testing. In the second experiment, rats were maintained on methadone during CPP testing, but not during conditioning. The absence of a CPP in both experiments would indicate that methadone can inhibit the expression of cocaine CPP without interfering with the direct reinforcing properties of cocaine. To directly test this hypothesis, we also studied the effect of methadone maintenance on intravenous self-administration of cocaine on a continuous schedule of reinforcement.

Furthermore, because the neuropharmacological consequences of long-term withdrawal from cocaine and methadone are virtually unknown, we removed the osmotic pumps in animals tested in the first CPP experiment, and extracted brains and plasma after a 14-day withdrawal period from cocaine/10-day withdrawal period from methadone. We quantified mu-opioid receptor (MOR) mRNA expression in the frontal cortex, nucleus accumbens core, caudate-putamen, amygdala, and hypothalamus. These regions were selected because of their known involvement in various behavioral and motivational aspects of drugs of abuse (Everitt and Wolf, 2002; Koob, 1992), and because they constitutively express MOR mRNA (Mansour et al, 1994). In addition, the arcuate nucleus of the hypothalamus contains neurons that express proopiomelanocortin (POMC) and which are presumably the sources of betaendorphins input to the nucleus accumbens (Finley et al, 1981). As the release of beta-endorphins in the nucleus accumbens is critical to drug- and non-drug-motivated behaviors (Roth-Deri et al, 2004; Zangen and Shalev, 2003), we also measured expression of POMC mRNA in the hypothalamus.

An additional quantification targeted components of the hypothalamic-pituitary-adrenal (HPA) axis. We assessed plasma adrenocorticotropic hormone (ACTH) and corticosterone (CORT) because they are known to be altered by chronic exposure to opiates and cocaine (Schluger et al, 2001; Zhou et al, 1999, 2003). Finally, because glucocorticoids exert a negative feedback control on the release of ACTH and beta-endorphins by the anterior pituitary, we quantified mRNA expression of their precursor (POMC) in this region.

\section{MATERIALS AND METHODS}

\section{Subjects}

Subjects were adult male Sprague-Dawley rats (Charles River, QC) weighing $225-250 \mathrm{~g}$ at the beginning of all experiments. They were singly housed and maintained on a reverse light/dark cycle ( $0800 \mathrm{~h}$ lights off; $2000 \mathrm{~h}$ lights on) with free access to food and water except during behavioral testing, which always occurred during the dark cycle. All experiments were approved by the Animal Care Committee of the University of Guelph and were carried out in accordance with the recommendations of the Canadian Council on Animal Care.

\section{Surgery}

Osmotic mini-pumps. Methadone maintenance was achieved by implanting osmotic mini pumps SC (Alzet model $2 \mathrm{ML} 2,0.5 \mu \mathrm{l}$ per hour for 14 days, Durect Corporation, Cupertino, CA). Isoflurane was used to anaesthetize the rats and a small incision between the scapulae was made in the skin. Subcutaneous connective tissues were spread apart using a hemostat to make a small pocket for the pump. Osmotic pumps were placed into the pocket with flow moderator directed away from the incision. Wound clips kept the incision closed. An identical procedure was carried out for the animals receiving sham surgery.

Intravenous self-administration. Rats were surgically implanted with intravenous silastic catheters (Dow Corning, Midland, MI) in the right jugular vein, under general anesthesia induced by a combination of sodium pentobarbital $(18.5 \mathrm{mg} / \mathrm{kg}$ i.p., MTC Pharmaceutical, Cambridge, $\mathrm{ON})$, morphine $(5 \mathrm{mg} / \mathrm{kg}$ s.c., Ontario Veterinary College, Guelph, ON) and diazepam (1 $\mathrm{mg} / \mathrm{kg}$ s.c., Sabex Inc., Boucherville, QC). Rats were given atropine sulfate $(4.5 \mathrm{mg} / \mathrm{kg}$ s.c., Ontario Veterinary College, Guelph, ON) just before surgery and depocillin $(300000 \mathrm{IU}, 0.1 \mathrm{ml} / \mathrm{rat}$ IM, Intervet Canada, Whitby, ON) immediately following 
surgery. The catheter was secured to the vein with silk sutures and was passed s.c. to the top of the skull, where it exited into a connector (a modified 22-gauge cannula; Plastics One, Roanoke, VA) mounted to the skull with jeweler's screws and dental cement. A plastic blocker was placed over the opening of the connector when not in use. Catheters were flushed daily with saline and every second day with $0.1 \mathrm{ml}$ of a saline-heparin solution $(0.2 \mathrm{mg} / \mathrm{ml}$ Hepalean $1.000 \mathrm{IU}$, Organon, Toronto, ON).

\section{Testing Apparatus}

Conditioned place preference. Six, custom-made (University of Guelph, ON, Canada), place conditioning boxes were used in these experiments. The boxes were located in the center of the laboratory room. Each conditioning box was made of dark gray PVC, and comprised of three compartments: two large $\left(30 \times 40 \times 26 \mathrm{~cm}^{3}\right)$ and one smaller, middle $\left(23 \times 30 \times 26 \mathrm{~cm}^{3}\right)$ compartment. Removable inserts, with or without small arch-way openings $\left(10 \times 10 \mathrm{~cm}^{2}\right)$, formed the center compartment. The two large compartments differed primarily in visual cues; one large compartment was dark gray, while the other had a white wall and a $10-\mathrm{cm}$ white stripe painted along the top of the other walls. In addition, there were cues that provided spatial information external to the compartments, such as posters on walls, benches, and lights. In this apparatus, rats do not display a significant spontaneous preference for any of the compartments (ie, the apparatus is balanced). The entire apparatus was covered by black wire mesh to allow video tracking of the rats during testing. The tracking software employed was EthoVision (version 3, Noldus Information Technology, The Netherlands). This system was used to record two dependent variables: time (s) spent in each compartment during test for place preference, and locomotor activity (total $\mathrm{cm}$ ) during conditioning and during place preference test.

Intravenous self-administration. In all, 20 Plexiglas operant chambers (model ENV-008CT, Med Associates, Lafayette, IN) were each enclosed in larger sound-attenuating plywood chambers (model ENV-018 M, Med Associates). Each operant box had a house light $(28 \mathrm{~V})$ and two levers, one retractable and one stationary, located $10 \mathrm{~cm}$ apart and $8 \mathrm{~cm}$ above the floor of the box. The retractable lever (active lever) was connected to an infusion pump for the delivery of drugs (Razel Scientific Instruments, Stamford, CT), positioned outside the sound-insulating chamber. The stationary lever served to control for baseline, nonreinforced operant behavior; pressing this lever had no consequence (inactive lever), but all presses were recorded. A white light $(28 \mathrm{~V})$ stimulus located $3 \mathrm{~cm}$ above the active lever was illuminated for $30 \mathrm{~s}$ at the beginning of the session, and for the duration of each drug infusion $(10 \mathrm{~s})$, serving as a discrete stimulus for drug delivery.

\section{Biochemical Assays}

Solution hybridization ribonuclease (RNase) protectiontrichloroacetic acid (TCA) precipitation assay. Immediately following decapitation, brains were extracted and the hypothalamus $(\mathrm{H})$ and anterior pituitary (AP) dissected out.
All tissue was rapidly frozen in dry ice, and stored at $-40^{\circ} \mathrm{C}$ for subsequent measurements of POMC mRNA in the $\mathrm{H}$ and AP. Mu-opioid receptor (MOR) mRNA was quantified in the hypothalamus, the frontal cortex (FC), the caudate putamen $(\mathrm{CP})$, the amygdala core (NACc), and the nucleus accumbens. Except for the hypothalamus, each structure was dissected out bilaterally by razor blade or hole-punch. For the nucleus accumbens, the hole-punches were centered on its core component (NACc), and therefore our results are limited to this subregion.

The solution hybridization RNase protection-TCA precipitation protocol has been described in detail in earlier reports (Branch et al, 1992). A $2100 \mathrm{bp}$ fragment from the rat MOR cDNA (a kind gift from Dr G Uhl of NIDA, MD) and a $538 \mathrm{bp}$ fragment from the rat POMC cDNA (a kind gift from Dr JL Roberts of Mount Sinai Medical Center in New York, NY) were cloned into the polylinker region of the pSP64 plasmid (Promega, Madison, WI) in both the sense and antisense orientations. The plasmid pS/E (a pSP65 derivative; a kind gift from Drs T Nilsen and P Maroney of Case Western University) was used to synthesize riboprobe for the 18 S rRNA to determine total RNA. ${ }^{33}$ P-labeled cRNA antisense probes and unlabeled RNA sense standards were synthesized using an SP6 transcription system. A denaturing agarose gel containing $1.0 \mathrm{M}$ formaldehyde showed that a single full-length transcript had been synthesized from each plasmid.

RNA extracts were dried in $1.5 \mathrm{ml}$ Eppendorf tubes and re-suspended in $30 \mu \mathrm{l}$ that contained 150000-300 000 c.p.m. of a probe in $2 \times$ TESS $(10 \mathrm{mM} \mathrm{N}$-Tris[hydroxy-methyl]methyl-2-aminoethane sulfonic acid, pH 7.4; 10 mM EDTA; $0.3 \mathrm{M} \mathrm{NaCl} ; 0.5 \%$ SDS). Samples were covered with mineral oil and hybridized overnight at $75^{\circ} \mathrm{C}$. For RNase treatment, $250 \mu \mathrm{l}$ of a buffer that contained $0.3 \mathrm{M} \mathrm{NaCl} ; 5 \mathrm{mM}$ EDTA; $10 \mathrm{mM}$ Tris- $\mathrm{HCl}$ ( $\mathrm{pH} 7.5$ ), $40 \mu \mathrm{g} / \mathrm{ml}$ RNase A (Worthington, Biochemicals, Freehold, NJ), and $2 \mu \mathrm{g} / \mathrm{ml}$ RNase T1 (Calbiochem, San Diego, CA) were added and each sample was incubated at $30^{\circ} \mathrm{C}$ for $1 \mathrm{~h}$. TCA precipitation was effected by the addition of $1 \mathrm{ml}$ of a solution that contained $5 \%$ TCA and $0.75 \%$ sodium pyrophosphate. Precipitates were collected onto a filter in sets of 24 by using a cell harvester (Brandel, Gaithersburg, MD) and were measured in a scintillation counter with liquid scintillant (Beckman Instruments, Palo Alto, CA).

The procedure to measure mRNA levels involved comparison of values obtained from experimental samples (brain extracts) to those obtained for a set of calibration standards. The calibration standards had known amounts of an in vitro sense transcript whose concentration was determined by optical absorbance at $260 \mathrm{~nm}$. To determine the total picograms of each mRNA in each extract, the amounts calculated from the standard curves were multiplied by 5.71 for MOR and by 2.04 for POMC to correct for the difference in length between the sense transcript (2100 and 538 bases for MOR and POMC respectively) and the full-length mRNA (12 and $1.1 \mathrm{k}$ base for MOR and POMC, respectively). Total cellular RNA concentrations were measured by hybridization of diluted extracts to a ${ }^{33} \mathrm{P}$ labeled probe complementary to $18 \mathrm{~S}$ rRNA at $75^{\circ} \mathrm{C}$. The calibration standards for this curve contained $10 \mu \mathrm{g}$ of Escherichia coli tRNA plus either 0.0, or from 2.5 to $40 \mathrm{ng}$ of total RNA from rat brain, whose concentration was determined by optical absorbance at $260 \mathrm{~nm}$. 
Radioimmunoassay. Trunk blood was collected immediately after decapitation, stored in tubes, placed on ice, and spun in a centrifuge. Plasma was separated and stored at $-40^{\circ} \mathrm{C}$ for CORT measurement by radioimmunoassay. CORT levels were assayed using a rat CORT ${ }^{125} \mathrm{I}$ kit from ICN Biomedicals (Costa Mesa, CA). ACTH immunoreactivity levels were assayed using a kit from Nichols Institute (San Juan Capistrano, CA). All CORT and ACTH values were determined in duplicate in a single assay, and intraassay coefficients of variation for CORT and ACTH were 1.5 and $4.1 \%$, respectively.

\section{Drugs}

Cocaine HCL (Dumex, Toronto, ON) and Methadone HCL (Pharmascience, Montreal, QC) were dissolved in physiological saline.

\section{Experiment 1: Effect of Methadone Maintenance on Formation and Expression of Cocaine CPP}

Procedure. Rats were allowed 6 days to habituate to the animal facility and were handled twice for approximately 10 min before the beginning of the experiment. The place conditioning procedure included three phases: habituation, conditioning, and testing.

Habituation: On this day, the inserts with openings were used, and rats had free access to the three compartments for $20 \mathrm{~min}$. The main purposes of this phase were to allow the rats to become accustomed to the apparatus, and to measure levels of spontaneous preference for each large compartment. The following day, animals were randomly assigned to three different methadone groups ( $n=24$ each) and implanted with osmotic mini-pumps. Methadone doses were 0,20 , and $55 \mathrm{mg} / \mathrm{kg} /$ day. In rats, it has been demonstrated that $10 \mathrm{mg} / \mathrm{kg} /$ day results in a mean plasma level of $123 \mathrm{ng} / \mathrm{ml}$ (range: $100-150 \mathrm{ng} / \mathrm{ml}$ ) (Zhou et al, 1996). In humans, a dose of $100 \mathrm{mg} /$ day results in an average daily concentration of about $240 \mathrm{ng} / \mathrm{ml}$ (Kreek, 2000). Thus, in this experiment, we used a methadone dose (ie, $20 \mathrm{mg} / \mathrm{kg} /$ day) corresponding to the high end of typical therapeutic ranges (Dole, 1988; Maxwell and Shinderman, 1999), and a dose more than twice as high (ie, $55 \mathrm{mg} / \mathrm{kg} /$ day).

Conditioning: This phase began 3 days following implant of methadone mini-pumps. During conditioning, the inserts with openings were replaced with solid inserts to fully separate the compartments. Rats underwent 3 days of conditioning, and each day they received two 30-min conditioning sessions, one in the morning and the other in the afternoon (morning session: between $0900 \mathrm{~h}$ and $1200 \mathrm{~h}$; afternoon session: between $1400 \mathrm{~h}$ and $1700 \mathrm{~h}$ ). Each day, rats received one conditioning session with cocaine (see doses below) and the other with vehicle. The specific compartment chosen to be associated with cocaine was counterbalanced across rats. In addition, the time of cocaine sessions was counterbalanced across rats and, for each rat, across days of conditioning. Injections were administered immediately before confinement in one of the two large compartments. Rats in each methadone dose group $(n=24$ each) were randomly assigned to three different cocaine doses $(n=8$ each): 1,5 , or $20 \mathrm{mg} / \mathrm{kg}$. Previous pilot studies using this apparatus and this conditioning procedure demonstrated that, in contrast to 1 and $5 \mathrm{mg} / \mathrm{kg}, 20 \mathrm{mg} / \mathrm{kg}$ produces a robust place preference. Cocaine doses of 1 and $5 \mathrm{mg} / \mathrm{kg}$ were included to evaluate the possibility that methadone maintenance may potentiate the rewarding efficacy of lower cocaine doses. It should be noted that, in order to interpret the biochemical analyses, an additional group of rats $(n=8)$ was included. These rats received identical behavioral manipulations, but were exposed neither to methadone (ie, received vehicle-filled pumps) nor to cocaine (received only vehicle injections during conditioning). The behavioral data from this control group are not included in the Results section.

Testing: Place preference was assessed on a test given 3 days following the last day of conditioning. For this test, the solid inserts were replaced by those with openings, and rats were given 20 min of free access to all compartments. At this time, rats were still maintained on methadone.

The day following this test, methadone pumps were removed using the anesthetic protocol described, and, after 10 days of withdrawal, all rats were euthanized using $\mathrm{CO}_{2}$, rapidly decapitated, and serum and brains collected for subsequent neurochemical analyses. This particular period of withdrawal was selected for two reasons. First, we have observed that 10 days are required for rats to recover bodyweight loss caused by withdrawal from heroin exposure via minipumps (Leri et al, 2003). Second, euthanasia occurred 14 days after the last cocaine conditioning injection, a time point relatively unexplored as most studies of cocaine-induced alterations in MOR mRNA levels have been limited to periods of acute $(3 \mathrm{~h})$ and early withdrawal (1-7 days)

Statistical analyses. In a three-compartment apparatus, place preference typically results from a decrease in time spent in the vehicle- and an increase in time spent in the drug-paired compartments (Leri and Rizos, 2005). Thus, our statistical analysis involves the comparison between these times within each group on the test day, a method used by a number of other laboratories employing the unbiased CPP procedure (Bardo et al, 1995; Everitt et al, 1991; Hoffman, 1989; Leri and Franklin, 2000; Mueller et al, 2002; Parker and Mcdonald, 2000). Typically, animals also spend a substantial amount of time in the middle compartment, both during habituation and during the test for CPP. However, this variable is not significantly altered by place conditioning and, therefore, it is not included in the behavioral analyses.

Place preference during test and locomotor activity during conditioning (average of conditioning sessions with vehicle and with cocaine) were analyzed using three-factor (methadone dose, cocaine dose, compartment/injection) mixed-design ANOVA (compartment/injection was within subjects). Locomotor activity during the test of preference was analyzed using a two-factor (methadone dose and cocaine dose) ANOVA with independent groups. Changes in body weight induced by spontaneous withdrawal from methadone were analyzed using a three-factor (methadone dose, cocaine dose, withdrawal day) mixed design ANOVA (withdrawal day was within subjects).

Plasma ACTH, plasma CORT, POMC in H, POMC in AP, and MOR mRNA in the FC, NACc, $\mathrm{CP}, \mathrm{A}$, and $\mathrm{H}$ were all 
analyzed separately. For each measure, a two-factor (methadone dose and cocaine dose) ANOVA with independent groups was performed first. Subsequently, a one-factor ANOVA with independent groups was performed to compare the control group (ie, no methadone and no cocaine) to the groups that received 1,5 , or $20 \mathrm{mg} / \mathrm{kg}$ cocaine. Separate analyses were performed for each group of rats that received different methadone doses (ie, vehicle, 20 and $55 \mathrm{mg} / \mathrm{kg} /$ day).

In case of significant interactions or significant main effects, multiple comparisons were performed using the Holm-Sidak method in order to identify individual mean differences. The alpha level was set to 0.05 .

\section{Experiment 2: Effect of Methadone Maintenance on Expression and Reinstatement of Cocaine CPP}

Procedures. Twelve rats were habituated and conditioned $(20 \mathrm{mg} / \mathrm{kg}$ cocaine) as described above, but in this experiment the methadone pumps $(0 \mathrm{mg} / \mathrm{kg} /$ day, $n=6 ; 55 \mathrm{mg} / \mathrm{kg} /$ day, $n=6$ ) were implanted after the last session of conditioning. Thus, there was no overlap between cocaine conditioning and methadone exposure. At 3 days after the implantation of the mini-pumps, animals received a place preference test as described above.

Following this test, the two groups underwent extinction of place preference. Extinction was similar to conditioning in that it was carried out over 3 days, with two 30-min conditioning sessions each day. However, during extinction, rats received vehicle injections before confinement in both compartments. Finally, two place preference tests were given over two consecutive days. Just prior to the first test, animals received a vehicle injection (ie, Vehicle Prime), while prior to the second test they received cocaine (ie, Cocaine Prime, $20 \mathrm{mg} / \mathrm{kg}$, i.p.). No neurochemical analyses were performed on plasma or brains at the conclusion of this experiment.

Statistical analyses. The main focus of this experiment was to determine how preference changed within each methadone group ( 0 and $55 \mathrm{mg} / \mathrm{kg} /$ day) across tests (CPP test, and tests given after extinction following vehicle and cocaine injections). Therefore, two separate two-factors repeatedmeasures ANOVAs (both test and compartment within subjects) were performed. Finally, a two-factors (methadone dose and priming injection) mixed-design ANOVA (priming injection was within subjects) was used to compare locomotion during the two post-extinction tests in the two groups.

\section{Experiments 3A and 3B: Effect of Methadone Maintenance on Intravenous Cocaine Self-Administration}

Procedure. Rats were placed in the chambers and their connectors attached to the infusion lines. Each session started with the activation of the house light, the entry of the retractable lever, and the illumination of the light stimulus for $30 \mathrm{~s}$. Subsequently, lever presses on the active lever led to drug infusions according to a continuous schedule of reinforcement. Drug was infused in a volume of $300 \mu \mathrm{l}$ over a 10-s period, and during this period the light stimulus was illuminated. Responses on the active lever made during the infusion were recorded, but did not lead to further infusions. Drug concentration was adjusted for differences in body weight.

In Experiment $3 \mathrm{~A}$, six rats were initially trained to selfadminister $2.0 \mathrm{mg} / \mathrm{kg} /$ infusion cocaine for five consecutive daily sessions, each lasting $3 \mathrm{~h}$. After this period, methadone-filled osmotic mini-pumps ( 0 and $55 \mathrm{mg} / \mathrm{kg} /$ day, $n=3$ each) were implanted and, following a 6-day recovery period, self-administration for the same dose of cocaine was evaluated during methadone maintenance on two test sessions given over two consecutive days.

In Experiment 3B, we increased the sample size and we performed a within-subjects dose-response analysis of cocaine self-administration in methadone-maintained rats. For this experiment, we reduced the methadone dose to $30 \mathrm{mg} / \mathrm{kg} /$ day because we had noticed toxicity (ie, rapid loss of body weight) in the rats tested in the previous selfadministration study. This methadone dose has previously been shown to decrease cocaine-seeking in animals trained to self-administer both heroin and cocaine (Leri et al, 2004).

Therefore, 12 rats were initially trained to self-administer $0.5 \mathrm{mg} / \mathrm{kg} /$ infusion cocaine for five consecutive daily sessions, each lasting $3 \mathrm{~h}$. After this period, methadonefilled osmotic mini-pumps ( 0 and $30 \mathrm{mg} / \mathrm{kg} /$ day, $n=6$ each) were implanted and, following a 6-day recovery period, selfadministration for the same dose of cocaine was evaluated during methadone maintenance on two self-administration test sessions given over two consecutive days. Subsequently, half of the animals in each group were transferred to a lower cocaine dose $(0.1 \mathrm{mg} / \mathrm{kg} /$ infusion $)$ and the other half to a higher cocaine dose $(2 \mathrm{mg} / \mathrm{kg} /$ infusion $)$, which they selfadministered for 2 days during methadone maintenance. The doses were reversed for the two final days of cocaine self-administration, always under methadone maintenance.

Statistical analyses. In both experiments, two-factor mixed-design ANOVAs were used to compare cocaine infusions (average of two days with the same dose) obtained before and after the implantation of methadone pumps.

\section{RESULTS}

\section{Experiment 1}

Conditioned place preference. Animals $(n=72)$ displayed no significant spontaneous preference for either compartment during habituation (mean (SEM): vehicle-to-beconditioned compartment $=350.3 \quad(8.7) \mathrm{s}$; cocaine-to-beconditioned compartment $=332.4(9.2) \mathrm{s}$ ). However, after conditioning, significant methadone dose by cocaine dose by compartment interaction $(\mathrm{F}(63143)=2.59, p<0.05)$ and significant cocaine dose by compartment interaction $(\mathrm{F}(2$, $143)=3.16, p<0.05$ ) were found. As it can be seen in Figure 1, animals conditioned with $20 \mathrm{mg} / \mathrm{kg}$ cocaine and not maintained on methadone $(0 \mathrm{mg} / \mathrm{kg} / \mathrm{day}$ methadone $)$ displayed a significant preference for the cocaine-paired compartment. Animals conditioned with $20 \mathrm{mg} / \mathrm{kg}$ cocaine and maintained on $20 \mathrm{mg} / \mathrm{kg}$ methadone showed a reduced CPP $(p=0.05)$. Finally, animals conditioned with $20 \mathrm{mg} / \mathrm{kg}$ cocaine and maintained on $55 \mathrm{mg} / \mathrm{kg}$ methadone showed no CPP. Thus, methadone blocked cocaine CPP in a dose- 


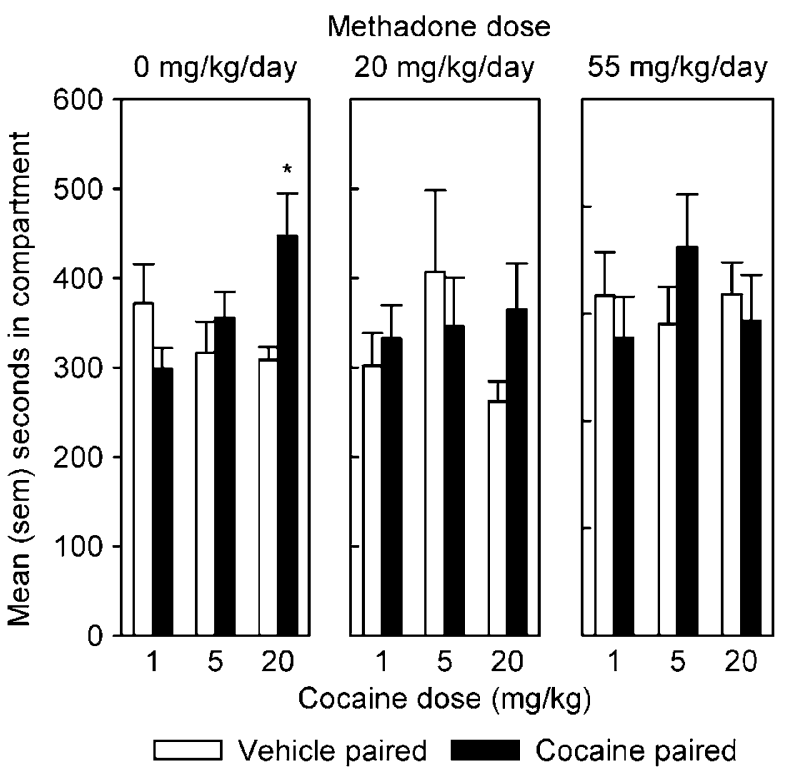

Figure I Mean (SEM) seconds spent in the vehicle- and the cocainepaired compartments on a 20-min place preference test. During conditioning and during test, different groups of animals ( $n=24$ each) were maintained on 0,20 , or $55 \mathrm{mg} / \mathrm{kg} /$ day methadone via osmotic minipumps. During conditioning, different subgroups of rats $(n=8)$ in each methadone dose group received I, 5 , or $20 \mathrm{mg} / \mathrm{kg}$ cocaine. * Denotes a significant difference between time in the vehicle- and the cocaine-paired compartments.

dependent manner. Methadone did not seem to potentiate the reinforcing efficacy of lower cocaine doses ( 1 and $5 \mathrm{mg} / \mathrm{kg}$ ), which, in fact, were ineffective in inducing a significant place preference in all groups.

Methadone maintenance did not alter locomotor responses to acute cocaine injections given during conditioning. In fact, as illustrated in Figure 2, 5 and $20 \mathrm{mg} / \mathrm{kg}$ cocaine elevated locomotion activity equally in all methadone groups (cocaine dose by compartment interaction $(\mathrm{F}(2,143)=86.6, p<0.001)$; main effect of cocaine dose $(\mathrm{F}(2,63)=61.4, p<0.001)$; and main effect of compartment $(\mathrm{F}(1,72)=244.4, \quad p<0.001))$. Also, although methadone maintenance blocked the expression of cocaine CPP induced by $20 \mathrm{mg} / \mathrm{kg}$, it did not significantly alter the level of locomotor activity during the test of preference (for example: mean (SEM) activity in group $20 \mathrm{mg} / \mathrm{kg}$ cocaine $-0 \mathrm{mg} / \mathrm{kg} /$ day methadone $=8211.2 \quad(289.8)$; mean (SEM) activity in group $20 \mathrm{mg} / \mathrm{kg}$ cocaine $-55 \mathrm{mg} / \mathrm{kg} / \mathrm{day}$ methadone $=8078.8(465.3)$ )

Spontaneous methadone withdrawal. As it can be seen in Figure $3,24 \mathrm{~h}$ following the removal of the methadone-filled mini-pumps, rats in the 20 and the $55 \mathrm{mg} / \mathrm{kg} /$ day groups lost a significant amount of body weight regardless of the cocaine dose received during conditioning (methadone dose by withdrawal day interaction $(\mathrm{F}(4,126)=10.2$, $p<0.001)$; main effect of methadone dose $(\mathrm{F}(2,63)=23.8$, $p<0.0001)$; main effect of withdrawal day $(\mathrm{F}(2,126)=$ $40.55, p<0.0001))$. By the time of euthanasia, 10 days following removal of the pumps, the body weight of rats in the $55 \mathrm{mg} / \mathrm{kg} /$ day group was still significantly lower than the body weight of rats in the $0 \mathrm{mg} / \mathrm{kg} /$ day group.

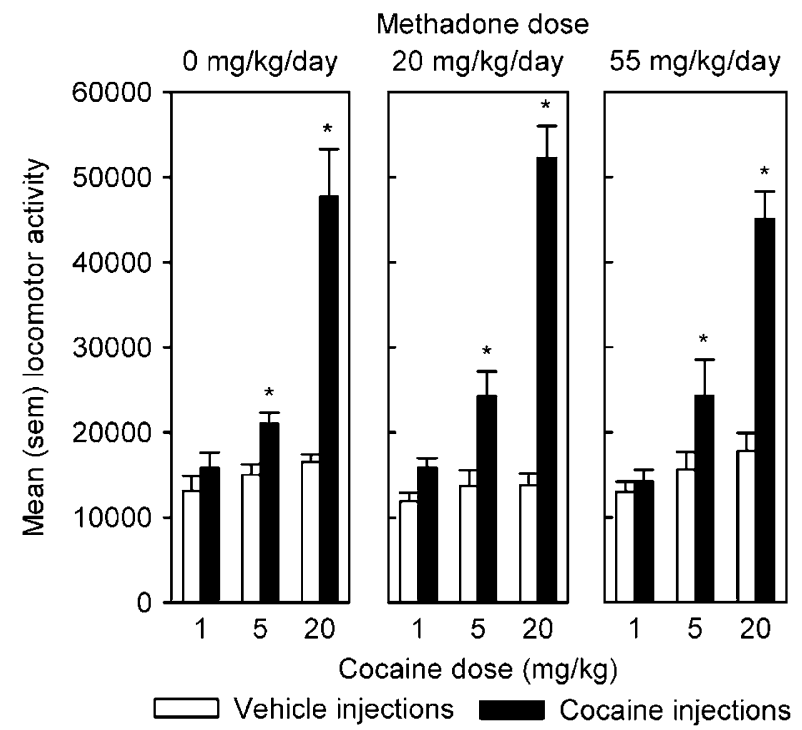

Figure 2 Mean (SEM) locomotor activity (average of the three sessions with vehicle and three sessions with cocaine) measured in each experimental group during place conditioning. * Denotes a significant difference between activity induced by vehicle and by cocaine injections.

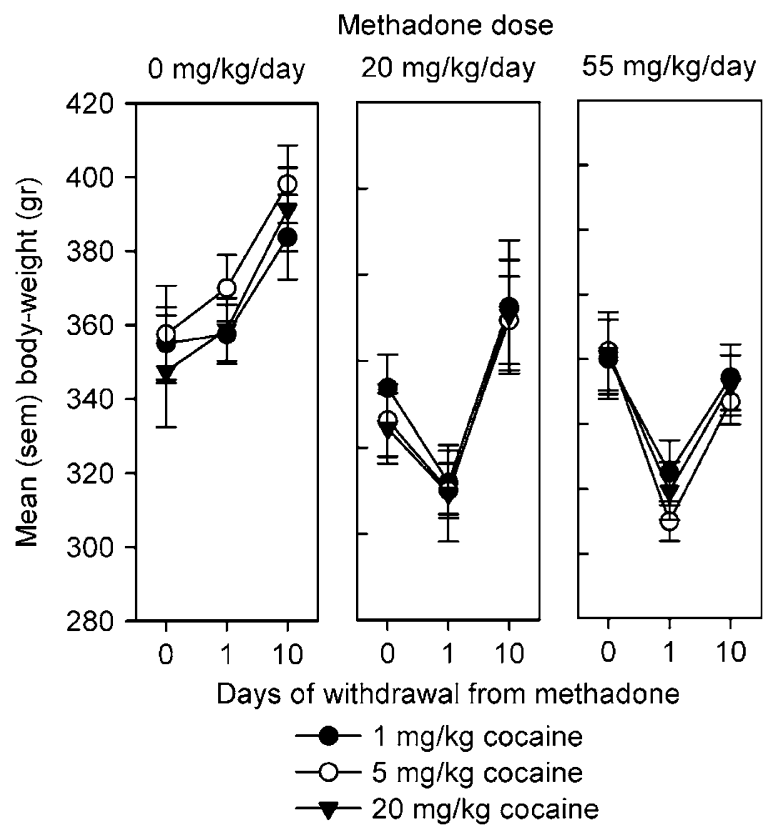

Figure 3 Mean (SEM) body weight measured in each experimental group upon removal of the methadone-filled minipumps (withdrawal day 0), $24 \mathrm{~h}$ (withdrawal day I), and 9 days later (withdrawal day I0).

HPA axis activity. ACTH in plasma: There was a significant interaction between methadone dose and cocaine dose $(\mathrm{F}(4,62)=2.55, p=0.05)$. Multiple comparisons indicated that rats exposed to $5 \mathrm{mg} / \mathrm{kg}$ cocaine during CPP and maintained on 20 and $55 \mathrm{mg} / \mathrm{kg} /$ day methadone showed significantly higher ACTH levels than rats exposed to $5 \mathrm{mg} / \mathrm{kg}$ cocaine only (see Table 1). When ACTH levels were compared within each methadone group to the control group (ie, no methadone and no cocaine), it was found that: in the $0 \mathrm{mg} / \mathrm{kg} /$ day methadone, animals previously exposed to $20 \mathrm{mg} / \mathrm{kg}$ cocaine showed significantly higher ACTH levels $(\mathrm{F}(3,26)=3.2, p<0.05)$; in the $20 \mathrm{mg} / \mathrm{kg} / \mathrm{day}$ 
Table I HPA Axis Activity in Experimental Subjects Killed 10 Days Following the Removal of the Methadone-Filled Osmotic Minipumps

Methadone maintenance dose $(\mathrm{mg} / \mathrm{kg} /$ day $)$

0

20

55

\begin{tabular}{|c|c|c|c|c|c|c|c|c|c|}
\hline \multicolumn{10}{|c|}{ Cocaine conditioning dose $(\mathrm{mg} / \mathrm{kg})$} \\
\hline $425.0(60)$ & $626.31(140)$ & $618.4(89)$ & $927.5(131)^{\#}$ & $810.1(96)^{\#}$ & $1116.5(142)^{\# \#}$ & $731.9(127)$ & $812.3(86)^{\#}$ & $962.6(85)^{\# \#}$ & $839.9(70)^{\#}$ \\
\hline \multicolumn{10}{|c|}{ Mean (SEM) CORT plasma (pg/ml) } \\
\hline \multicolumn{10}{|c|}{ Mean (SEM) POMC mRNA in AP ( $p g / \mu g$ total RNA) } \\
\hline$|24.3|(20.50)$ & $85.06(10.73)^{\#}$ & $67.66(7.25)^{\#}$ & $63.30(6.06)^{\#}$ & $79.48(11.87)^{\#}$ & $72.78(11.47)^{\#}$ & $69.66(9.49)^{\#}$ & $64.92(7.81)^{\#}$ & $68.42(11.90)^{\#}$ & $72.54(9.23)^{\ddagger}$ \\
\hline \multicolumn{10}{|c|}{ Mean (SEM) POMC mRNA in H ( $p g / \mu g$ total RNA) } \\
\hline
\end{tabular}

methadone group, although ACTH levels were elevated in each cocaine dose group, only levels in the 1 and $5 \mathrm{mg} / \mathrm{kg}$ cocaine groups were significantly different from controls $(\mathrm{F}(3,27)=6.0, p<0.005)$; finally, in the $55 \mathrm{mg} / \mathrm{kg}$ group, animals in all cocaine dose groups showed higher ACTH levels than controls $(\mathrm{F}(3,27)=8.5, p<0.001)$.

CORT in plasma: No significant differences were found (see Table 1).

$P O M C$ in the AP: There was no interaction between methadone dose and cocaine dose on POMC mRNA expressed in the anterior pituitary. Animals in all cocaine dose groups showed significant lower expression levels than controls, and this was observed in all methadone groups (Table 1: $0 \mathrm{mg} / \mathrm{kg} /$ day group $(\mathrm{F}(3,25)=5.6, p<0.005)$; $20 \mathrm{mg} / \mathrm{kg} /$ day group $(\mathrm{F}(3,24)=3.2, p<0.05) ; 55 \mathrm{mg} / \mathrm{kg} /$ day group $(\mathrm{F}(3,23)=4.5, p<0.05))$.

$P O M C$ in the $H$ : No significant differences were found (see Table 1).

MOR mRNA. FC: There was no interaction between methadone dose and cocaine dose on MOR mRNA expressed in the FC. Animals in all cocaine dose groups showed significantly higher expression levels than controls, and this was observed in all methadone groups (Table 2: $0 \mathrm{mg} / \mathrm{kg} /$ day group $(\mathrm{F}(3,27)=3.9, p<0.05) ; 20 \mathrm{mg} / \mathrm{kg} /$ day group $(\mathrm{F}(3,27)=9.7, p<0.001) ; 55 \mathrm{mg} / \mathrm{kg} /$ day group $(\mathrm{F}(3$, 28) $=4.7, p<0.01))$.

$N A C c$ : As illustrated in Figure 4, MOR mRNA expression was elevated in rats conditioned with 5 and $20 \mathrm{mg} / \mathrm{kg}$ cocaine, and methadone maintenance reduced this effect in a dose-dependent manner $(\mathrm{F}(2,58)=8.81, p<0.001)$. Thus, when compared to controls, MOR mRNA was significantly elevated in animals exposed to 5 and $20 \mathrm{mg} / \mathrm{kg}$ cocaine and maintained on $0 \mathrm{mg} / \mathrm{kg} /$ day methadone $(\mathrm{F}(3,25)=5.8$, $p<0.005)$. This elevation was reduced in animals maintained on $20 \mathrm{mg} / \mathrm{kg} /$ day methadone, but it was still significant $(\mathrm{F}(3,26)=3.7, p<0.05)$. However, in rats maintained on $55 \mathrm{mg} / \mathrm{kg} /$ day methadone, MOR mRNA levels were undistinguishable from controls regardless of the dose of cocaine given during CPP.

$C P$ : No significant differences were found (see Table 2).

$A$ : No significant differences were found (see Table 2).

$H$ : No significant differences were found (see Table 2).

\section{Experiment 2}

Two rats in the $0 \mathrm{mg} / \mathrm{kg} /$ day methadone group experienced post-surgical complications, and were thus removed from the study. The ANOVA performed within this group identified a significant main effect of compartment $(\mathrm{F}(1,9)=22.2, p<0.001)$. As it can be seen in panel a of Figure 5 , these rats $(n=4)$ displayed a significant place preference for the cocaine-paired compartment $(20 \mathrm{mg} / \mathrm{kg})$ on the initial test. Extinction training eliminated such a preference and, in fact, following the vehicle prime, there was no significant difference in times spent in the two conditioning compartments. Finally, a priming injection of $20 \mathrm{mg} / \mathrm{kg}$ cocaine just prior to the final test effectively reinstated the original cocaine place preference. Interestingly, when the same analysis was performed in the $55 \mathrm{mg} /$ $\mathrm{kg}$ /day methadone group (panel c, Figure 5), no significant differences were found. In other words, these animals showed no preference on all CPP tests. It is notable, however, that the cocaine prime increased locomotor activity equally in both groups of animals (panels $b$ and d, Figure 5; significant main effect of priming injection $(\mathrm{F}(1,8)=28.8, p<0.001)$ only $)$.

\section{Experiment 3A}

By the fourth and fifth days of self-administration, rats were responding almost exclusively on the active lever producing 
Table 2 Expression of MOR mRNA in Experimental Subjects Killed 10 Days Following the Removal of the Methadone-Filled Osmotic Minipumps

Methadone maintenance dose (mg/kg/day)

Cocaine conditioning dose $(\mathrm{mg} / \mathrm{kg})$

\begin{tabular}{|c|c|c|c|c|c|c|c|c|c|}
\hline 0 & $\mathbf{I}$ & 5 & 20 & $\mathbf{I}$ & 5 & 20 & $\mathbf{I}$ & 5 & 20 \\
\hline \multicolumn{10}{|c|}{ Mean (SEM) MOR mRNA in FC (pg/ $\mu \mathrm{g}$ Total RNA) } \\
\hline $2.11(0.12)$ & $3.01(0.27)^{\#}$ & $3.26(0.26)^{\#}$ & $3.08(0.29)^{\#}$ & $3.14(0.23)^{\#}$ & $3.04(0.26)^{\#}$ & $3.65(0.22)^{\#}$ & $3.52(0.47)^{\#}$ & $3.14(0.36)^{\#}$ & $3.64(0.28)^{\#}$ \\
\hline \multicolumn{10}{|c|}{ Mean (SEM) MOR mRNA in CP ( $p g / \mu \mathrm{g}$ total RNA) } \\
\hline $3.75(0.58)$ & $5.06(0.52)$ & $5.20(0.94)$ & $5.16(0.31)$ & $5.45(0.45)$ & $5.61(0.90)$ & $6.38(0.90)$ & $5.26(0.43)$ & $4.87(0.56)$ & $6.38(0.80)$ \\
\hline $10.47(0.56)$ & $8.42(0.83)$ & $8.90(0.98)$ & $8.70(0.77)$ & $8.83(1.02)$ & $7.77(0.49)$ & $7.53(0.44)$ & $9.86(1.38)$ & $8.15(0.74)$ & $8.85(0.95)$ \\
\hline \multicolumn{10}{|c|}{ Mean (SEM) MOR mRNA in $H$ ( $\mathrm{pg} / \mu \mathrm{g}$ total RNA) } \\
\hline $3.43(0.56)$ & $3.77(0.23)$ & $4.51(0.38)$ & $3.68(0.26)$ & $3.51(0.40)$ & $3.64(0.17)$ & $3.80(0.26)$ & $3.50(0.19)$ & $3.83(0.26)$ & $3.36(0.31)$ \\
\hline
\end{tabular}

$\mathrm{FC}=$ frontal cortex $\mathrm{CP}=$ caudate-putamen; $\mathrm{A}=$ amygdala; $\mathrm{H}=$ hypothalamus.

\#Significant difference from the control group.

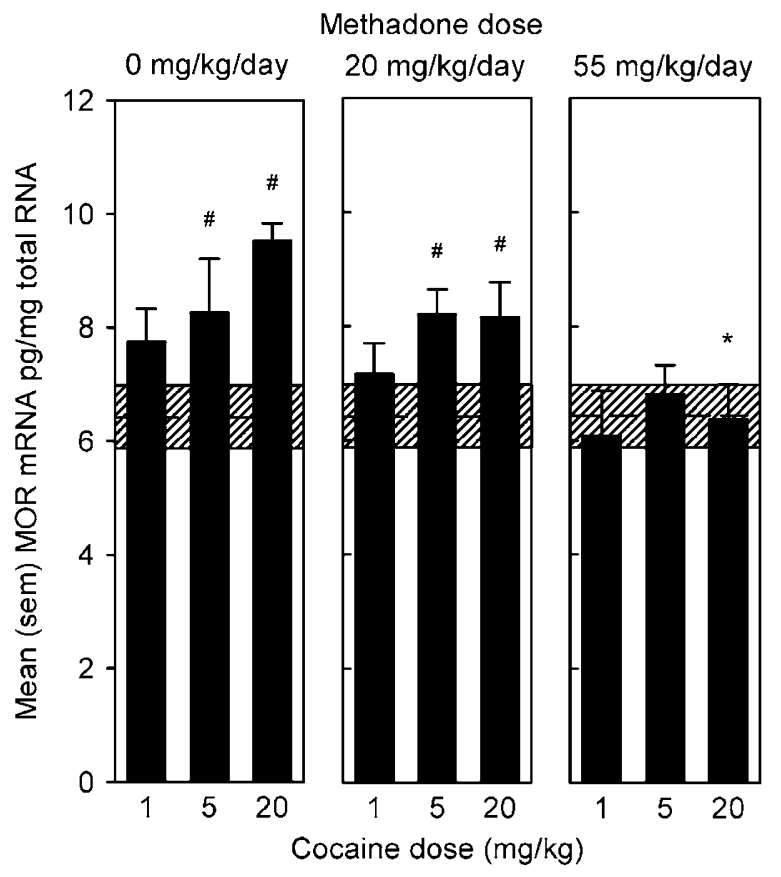

Figure 4 Mean (SEM) MOR mRNA expressed in the nucleus accumbens core of experimental subjects killed 10 days following the removal of the methadone-filled osmotic minipumps. The shaded area in each panel represents the data from the control group $(n=8)$ that received no methadone and no cocaine. The upper and lower borders represent the SEM, while the central horizontal line represents the group mean. *Denotes a significant difference from the same cocaine dose group in the $0 \mathrm{mg} / \mathrm{kg} /$ day methadone group. ${ }^{\#}$ Denotes a significant difference from the control group.

intravenous infusions of cocaine (96 and 95\% of total responding, respectively). As indicated in Figure 6a, there was no significant change in mean number of cocaine infusions obtained during the two sessions preceding, and the two sessions following, the implantation of the methadone-filled mini-pumps.

\section{Experiment 3B}

By the fourth and fifth days of self-administration, rats were responding almost exclusively on the active lever producing intravenous infusions of cocaine (93 and $99 \%$ of total responding, respectively). One animal from the methadone group had to be excluded from the experiment because of poor health. The ANOVA revealed a main effect of dose $(\mathrm{F}(3,27)=15.4, p<0.001)$, but no group differences. In other words, animals took more infusions when the dose of cocaine was lowered from 0.5 to $0.1 \mathrm{mg} / \mathrm{kg} /$ infusion, and fewer infusions when the cocaine dose was increased to $2.0 \mathrm{mg} / \mathrm{kg} /$ infusion, but these shifts in self-administration were similar in animals maintained on 0 and $30 \mathrm{mg} / \mathrm{kg} / \mathrm{day}$ methadone (see Figure 6b).

\section{DISCUSSION}

These studies were designed to: (1) explore the effects of high-dose methadone maintenance ( 20 and $55 \mathrm{mg} / \mathrm{kg} /$ day) on cocaine-seeking behavior assessed by the CPP procedure; (2) explore the effects of high-dose methadone maintenance (30 and $55 \mathrm{mg} / \mathrm{kg} /$ day) on cocaine-taking behavior assessed by the intravenous self-administration procedure using a continuous schedule of reinforcement; (3) explore the effect of methadone maintenance on the expression of mu-opioid receptor mRNA in mesocorticolimbic structures in animals that underwent cocaine CPP; and (4) explore the effect of methadone maintenance on the activity of the HPA axis in animals that underwent cocaine CPP. 

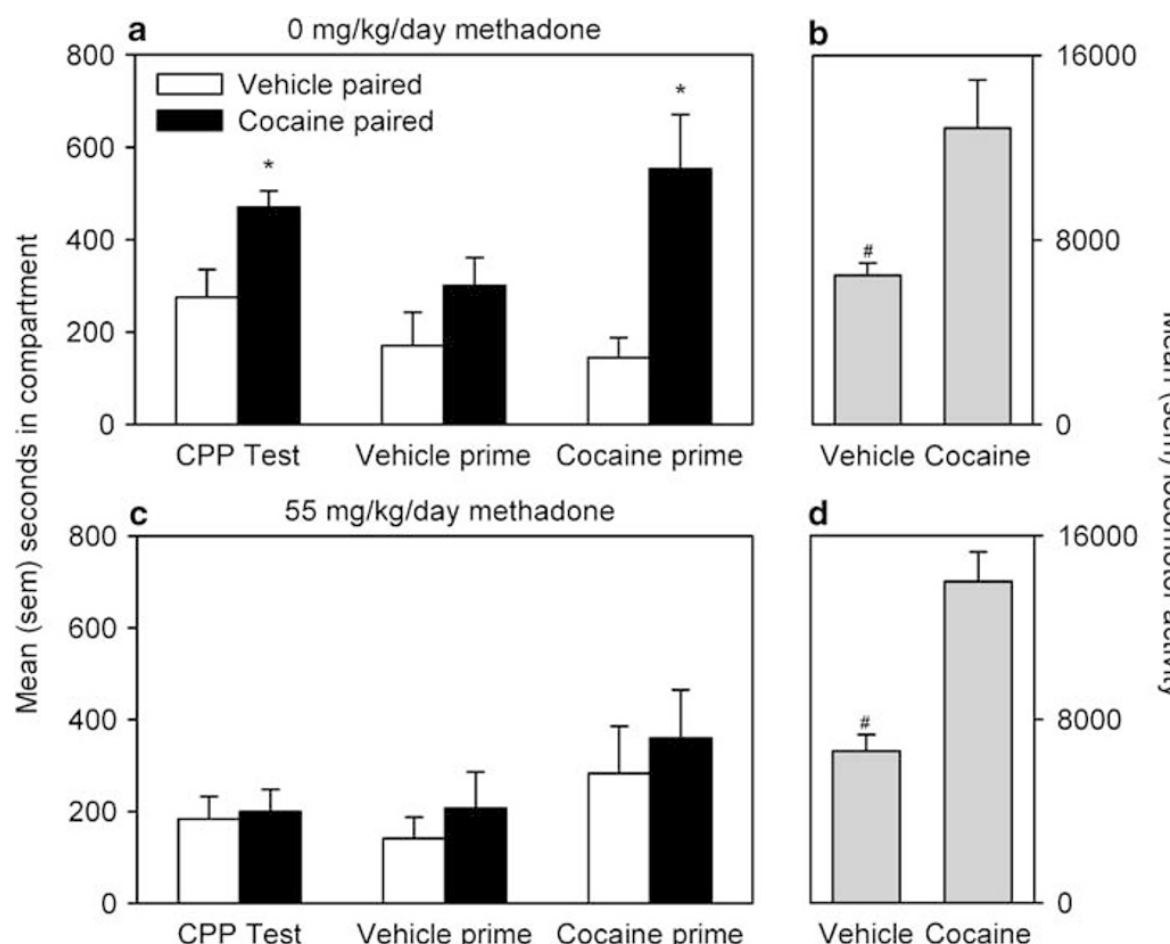

Figure 5 Mean (SEM) seconds spent in the vehicle- and the cocaine-paired compartments on three 20-min place preference tests. Prior to the first test (CPP test), different groups of animals were implanted with $0(n=4$; panel a, b) and 55 ( $n=6$; panel c, d) mg/kg/day methadone-filled osmotic minipumps, During conditioning, all rats received $20 \mathrm{mg} / \mathrm{kg}$ cocaine. Following extinction training, rats were tested after a vehicle injection (Vehicle prime), and on the subsequent day, after an injection of cocaine $(20 \mathrm{mg} / \mathrm{kg}$; cocaine prime). * Denotes a significant difference between time in the vehicle- and the cocainepaired compartments. Panels $b$ and d illustrate the mean (SEM) locomotor activity displayed by the 0 and the $55 \mathrm{mg} / \mathrm{kg} / \mathrm{day}$ methadone groups during the reinstatements tests, respectively. ${ }^{\#}$ Denotes a significant increase in locomotion between the vehicle and the cocaine prime tests.

The CPP procedure was used to model both spontaneous (Bardo and Bevins, 2000) and cocaine-precipitated (Mueller and Stewart, 2000) cocaine seeking. In the first CPP experiment, animals were maintained on methadone $(0$, 20 , and $55 \mathrm{mg} / \mathrm{kg} /$ day) during both conditioning and testing. Although methadone maintenance did not alter locomotor responses to cocaine injections given during the course of conditioning, it blocked the expression of cocaine $(20 \mathrm{mg} / \mathrm{kg})$ CPP in a dose-dependent manner. The lack of preference was particularly marked in rats maintained on the highest methadone dose (ie, $55 \mathrm{mg} / \mathrm{kg} /$ day), and was not due to methadone-induced inhibition/excitation of basal locomotor activity as no group differences in locomotion were observed during CPP test. In the same experiment, no evidence of potentiation of cocaine CPP by methadone was observed, as low cocaine doses ( 1 and $5 \mathrm{mg} / \mathrm{kg}$ ) failed to induce a significant place preference in all groups (ie, 0,20 and $55 \mathrm{mg} / \mathrm{kg} /$ day methadone).

In the second CPP experiment, the methadone pumps (0 and $55 \mathrm{mg} / \mathrm{kg} /$ day $)$ were implanted after cocaine $(20 \mathrm{mg} / \mathrm{kg})$ conditioning. Consistent with the results of the previous study, animals maintained on methadone did not express a significant place preference for the cocaine-paired compartment. Furthermore, it was found that priming injections of cocaine $(20 \mathrm{mg} / \mathrm{kg})$ had no effect on the expression of place preference in methadone-maintained rats, although locomotor activation produced by the cocaine prime was unaltered by methadone maintenance.

There are several possible explanations as to why highdose methadone maintenance blocked cocaine CPP. For example, it could be argued that the expression of cocaine CPP was influenced by state-dependent learning. However, this interpretation cannot account for the results of Experiment 1 where rats were both conditioned and tested while maintained on methadone. It could also be argued that methadone blocked the expression of CPP because it produced a memory impairment, resulting in complete forgetting of associations learned during conditioning. It has been found that methadone produces spatial learning and working memory impairments in rats (Hepner et al, 2002), but this was observed after acute injections, not during chronic maintenance.

In contrast to the results of the CPP studies, it was found that methadone maintenance ( 30 and $55 \mathrm{mg} / \mathrm{kg} /$ day) did not alter the intravenous intake of various doses of cocaine available on a continuous schedule of reinforcement. Furthermore, Leri et al (2004) found that stress, unlike cocaine and heroin primes, was effective in reinstating drug-seeking behavior in methadone-maintained rats. Therefore, taken together, these results indicate that the direct reinforcing effects of cocaine are not altered by methadone maintenance, and they further suggest that methadone maintenance does not block the expression of all goal-motivated behaviors because of general cognitive or motivational impairments. It is important to note that these results may be in part attributable to the chronic pattern of methadone exposure. In fact, unlike maintenance, acute injections of methadone do enhance cocaine CPP in rats (Bilsky et al, 1992) and monkeys prefer methadone-cocaine combinations over cocaine alone (Wang et al, 2001). 

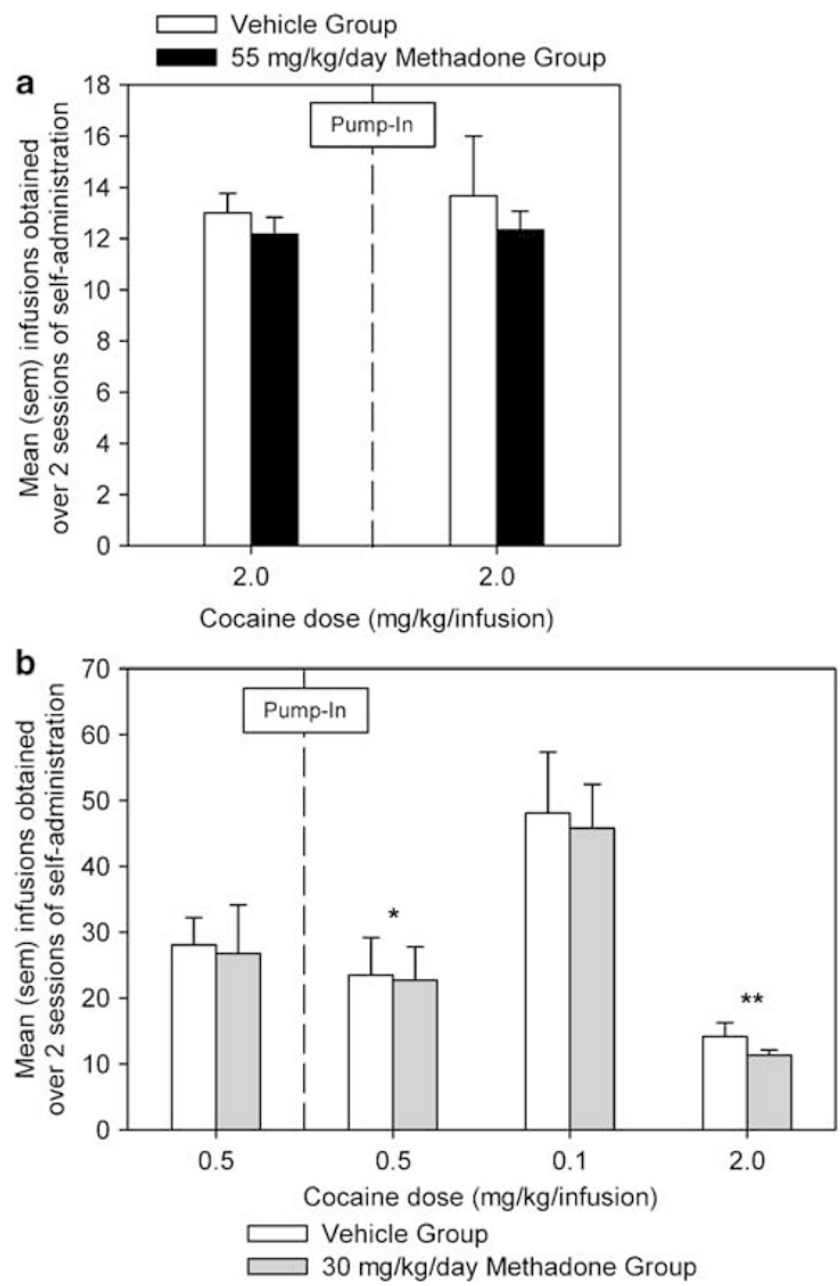

Figure 6 Panel a: Mean (SEM) infusions obtained over two sessions of intravenous self-administration of cocaine $(2 \mathrm{mg} / \mathrm{kg} /$ infusion $)$ before and after the implantation of methadone-filled ( 0 and $55 \mathrm{mg} / \mathrm{kg} / \mathrm{day}$ ) osmotic mini-pumps. Panel b: Mean (SEM) infusions obtained over two sessions of intravenous self-administration of cocaine before and after the implantation of methadone-filled ( 0 and $30 \mathrm{mg} / \mathrm{kg} /$ day) osmotic minipumps. Animals were trained with $0.5 \mathrm{mg} / \mathrm{kg} /$ infusion cocaine and, after pump-implantation, were tested with $0.5,0.1$, and $2 \mathrm{mg} / \mathrm{kg} /$ infusion cocaine. * Denotes a significant increase in infusions from 0.5 to $0.1 \mathrm{mg} / \mathrm{kg} /$ infusion, and ** denotes a significant decrease in infusions from 0.1 to $2 \mathrm{mg} / \mathrm{kg} /$ infusions.

Taken together, our studies in rats suggest that high-dose methadone maintenance does not alter the direct stimulatory and reinforcing properties of cocaine, but effectively reduces spontaneous and cocaine-precipitated cocaine seeking. Such results appear to parallel findings in opiatedependent individuals maintained on $50-100 \mathrm{mg} /$ day methadone who report unaltered (Foltin and Fischman, 1996), or enhanced (Foltin et al, 1995; Preston et al, 1996), cocaine-induced stimulation and cocaine liking, and yet consume less cocaine (Borg et al, 1999; Schottenfeld et al, 2005; Stine et al, 1992). A critical question that we are currently exploring is whether high-dose methadone maintenance can block seeking behaviors motivated by stimuli associated with other rewards such as palatable food or sexual behavior.

Methadone-maintained animals that underwent cocaine CPP in the first experiment were killed 10 days after removal of the methadone-filled minipumps. This time point was also selected to reduce the possibility that MOR were still being directly activated by residual levels of methadone in the brain. In humans, active methadone maintenance downregulates opioid-binding sites, and lowers both affinity and receptor availability (Kling et al, 2000). In the present study, we found a significant upregulation of MOR mRNA expression in the NAC core and FC of cocaineconditioned rats maintained on vehicle. However, animals maintained on 20 and $55 \mathrm{mg} / \mathrm{kg} /$ day methadone displayed a dose-dependent blockade of upregulation of MOR mRNA in the NAC core. The mechanisms by which methadone maintenance modulated MOR mRNA levels in the nucleus accumbens core are not clear. In fact, such an effect may result either from methadone's agonistic action at MOR (Kreek et al, 2002) or from its antagonistic action at NMDA glutamate receptors (Gorman et al, 1997). Two lines of evidence, however, support the former possibility. First, we have found that chronic exposure to morphine $(0,10$, and $20 \mathrm{mg} / \mathrm{kg} /$ day), an agent that has no direct antagonist action at NMDA receptors, dose dependently blocked cocaine (10 mg/kg) CPP (unpublished observation). Second, Zhou et al (2004) have found that chronic exposure to morphine leads to alterations in mRNA for MOR in the nucleus accumbens measured $12 \mathrm{~h}$ after the last morphine injection.

Our analysis of MOR mRNA expression suggests the possibility that methadone maintenance may have blocked the expression of cocaine CPP, at least in part, by preventing upregulation of MOR in the nucleus accumbens core induced by cocaine conditioning. The nucleus accumbens core mediates the motivational influence of Pavlovian stimuli on goal-directed behavior (Hall et al, 2001) and can therefore control drug-seeking activity. In fact, various manipulations of this region have been found to block cocaine CPP, operant responding for cocaineconditioned cues, cocaine-induced reinstatement of cocaine seeking, cocaine self-administration on a second-order schedule, and acquisition/expression of drug seeking maintained by cocaine-conditioned stimuli (Baker et al, 1998; Cornish and Kalivas, 2000; Duvauchelle et al, 2000; Fuchs et al, 2004; Grimm et al, 2003; Ito et al, 2000, 2004; Kaddis et al, 1995; McFarland and Kalivas, 2001; Wise, 2004). Also, our observation of lack of effect of methadone on MOR mRNA upregulation in the FC, and lack of effect of methadone on cocaine self-administration supports the idea that the FC mediates the subjective motivational properties of cocaine, while the nucleus accumbens core is involved in stimulated drug-seeking activity (Everitt and Wolf, 2002). However, because of the design of our study, it is not possible to attribute the effects of methadone on cocaineseeking behavior to the alterations of MOR mRNA we detected 14 days following behavioral testing. Nevertheless, this is a likely hypothesis which we are currently testing by measuring MOR mRNA expression on the same day of behavioral testing.

It is fairly well established that exposure to drugs of abuse produce dynamic changes in the state of activation of the HPA axis (Kreek et al, 2002). In rats, acute injections of cocaine increase plasma levels of ACTH and CORT (Moldow and Fischman, 1987), possibly via a stimulation of corticotropin-releasing factor in the hypothalamus. The effects of chronic cocaine exposure on HPA axis activity are more variable and influenced by the specific regimen of 
cocaine exposure (Torres and Rivier, 1992; Zhou et al, 2003). More importantly, several of these cocaine-induced alterations of the HPA axis appear to persist for some period of time following cocaine exposure, an observation that may explain the long-lasting vulnerability to stressinduced relapse in abstinent cocaine addicts (Goeders, 2002; Shaham et al, 2000; Sinha et al, 2000). The results obtained in the current study are certainly consistent with the suggestion that cocaine induces alterations of the HPA which outlast the period of active drug exposure. In fact, it was found that cocaine CPP dose-dependently increased both plasma ACTH and CORT, although CORT values did not reach statistical significance. This is a notable effect because animals only received three cocaine injections (5 or $20 \mathrm{mg} / \mathrm{kg}$ each) over 3 days of conditioning, and because ACTH and CORT were measured 14 days after the last cocaine injection.

Arguably, however, a surprising result was the limited effect of high-dose methadone maintenance on the HPA axis. In fact, when we analyzed the plasma and brain of rats 10 days following the removal of methadone-filled mini pumps, the only significant effect was on ACTH; methadone maintenance potentiated cocaine-induced increases in ACTH. This synergy, however, probably resulted from the effects of methadone withdrawal which, similarly to withdrawal from other opioids, induces hyperactivity of the HPA axis (Kreek, 2000). We suspect that this may be the case because removal of the pumps precipitated a state of opiate withdrawal as indicated by a rapid loss of body weight (Leri et al, 2003), which, in the $55 \mathrm{mg} / \mathrm{kg} /$ day methadone group, was not fully recovered by the time of euthanasia. Besides this effect on ACTH, high-dose methadone maintenance did not alter plasma CORT or POMC mRNA expression in the anterior pituitary or the hypothalamus. These results extend previous findings by Zhou et al (1996), who found that POMC mRNA expression in the anterior pituitary and hypothalamus as well as circulating levels of CORT were not altered during methadone maintenance $(10 \mathrm{mg} / \mathrm{kg} /$ day $)$.

In summary, the present experiments in rats show that high-dose methadone maintenance can effectively reduce spontaneous and cocaine-precipitated cocaine-seeking without altering the direct stimulatory and reinforcing effects of cocaine. In addition, our results suggest the hypothesis that methadone maintenance blocks cocaine seeking by inhibiting the upregulation of MOR mRNA expression in the nucleus accumbens core induced by cocaine conditioning.

\section{ACKNOWLEDGEMENTS}

These studies were supported by an Interdisciplinary Health Research Team grant from the Canadian Institutes of Health Research by the Canada Foundation for Innovation, Ontario Innovation Trust (FL), and by a NIDA Center Grant P60-DA-05130 (MJK).

\section{REFERENCES}

Azaryan AV, Coughlin LJ, Buzas B, Clock BJ, Cox BM (1996). Effect of chronic cocaine treatment on mu- and delta-opioid receptor mRNA levels in dopaminergically innervated brain regions. Neurochem 66: 443-448.
Baker DA, Fuchs RA, Specio SE, Khroyan TV, Neisewander JL (1998). Effects of intraaccumbens administration of SCH-23390 on cocaine-induced locomotion and conditioned place preference. Synapse 30: 181-193.

Bardo MT, Bevins RA (2000). Conditioned place preference: what does it add to our preclinical understanding of drug reward? Psychopharmacology 153: 31-43.

Bardo MT, Rowlett JK, Harris MJ (1995). Conditioned place preference using opiate and stimulant drugs: a metaanalysis. Neurosci Biobehav Rev 19: 39-51.

Bilsky EJ, Montegut MJ, Delong CL, Reid LD (1992). Opioidergic modulation of cocaine conditioned place preferences. Life Sci 50: L85-L90.

Borg L, Broe DM, Ho A, Kreek MJ (1999). Cocaine abuse sharply reduced in an effective methadone maintenance program. J Addict Dis 18: 63-75.

Branch AD, Unterwald EM, Lee SE, Kreek MJ (1992). Quantitation of preproenkephalin mRNA levels in brain regions from male Fischer rats following chronic cocaine treatment using a recently developed solution hybridization assay. Brain Res Mol Brain Res 14: 231-238.

Cornish JL, Kalivas PW (2000). Glutamate transmission in the nucleus accumbens mediates relapse in cocaine addiction. J Neurosci 20: RC89.

Dolan MP, Black JL, Penk WE, Robinowitz R, Deford HA (2001). Predicting the outcome of contingency contracting for drug abuse. Behav Ther 17: 470-474.

Dole VP (1988). Implications of methadone maintenance for theories of narcotic addiction. JAMA 260: 3025-3029.

Duvauchelle CL, Ikegami A, Castaneda E (2000). Conditioned increases in behavioral activity and accumbens dopamine levels produced by intravenous cocaine. Behav Neurosci 114: 11561166.

Everitt BJ, Morris KA, O'Brien A, Robbins TW (1991). The basolateral amygdala-ventral striatal system and conditioned place preference: further evidence of limbic-striatal interactions underlying reward-related processes. Neuroscience 42: 1-18.

Everitt BJ, Wolf ME (2002). Psychomotor stimulant addiction: a neural systems perspective. J Neurosci 22: 3312-3320.

Finley JC, Lindstrom P, Petrusz P (1981). Immunocytochemical localization of beta-endorphin-containing neurons in the rat brain. Neuroendocrinology 33: 28-42.

Foltin RW, Christiansen I, Levin FR, Fischman MW (1995). Effects of single and multiple intravenous cocaine injections in humans maintained on methadone. J Pharmacol Exp Ther 275: 38-47.

Foltin RW, Fischman MW (1996). Effects of methadone or buprenorphine maintenance on the subjective and reinforcing effects of intravenous cocaine in humans. J Pharmacol Exp Ther 278: 1153-1164.

Fuchs RA, Evans KA, Parker MC, See RE (2004). Differential involvement of the core and shell subregions of the nucleus accumbens in conditioned cue-induced reinstatement of cocaine seeking in rats. Psychopharmacology 176: 459-465.

Goeders NE (2002). Stress and cocaine addiction. J Pharmacol Exp Ther 301: 785-789.

Gorelick DA, Kim YK, Bencherif B, Boyd SJ, Nelson R, Copersino $\mathrm{M}$ et al (2005). Imaging brain mu-opioid receptors in abstinent cocaine users: time course and relation to cocaine craving. Biol Psychiatry 57: 1573-1582.

Gorman AL, Elliott KJ, Inturrisi CE (1997). The d- and l-isomers of methadone bind to the non-competitive site on the $N$-methyl-Daspartate (NMDA) receptor in rat forebrain and spinal cord. Neurosci Lett 223: 5-8.

Grella CE, Anglin MD, Wugalter SE (1997). Patterns and predictors of cocaine and crack use by clients in standard and enhanced methadone maintenance treatment. Am J Drug Alcohol Abuse 23: $15-42$. 
Grimm JW, Lu L, Hayashi T, Hope BT, Su TP, Shaham Y (2003). Time-dependent increases in brain-derived neurotrophic factor protein levels within the mesolimbic dopamine system after withdrawal from cocaine: implications for incubation of cocaine craving. J Neurosci 23: 742-747.

Hall J, Parkinson JA, Connor TM, Dickinson A, Everitt BJ (2001). Involvement of the central nucleus of the amygdala and nucleus accumbens core in mediating Pavlovian influences on instrumental behaviour. Eur J Neurosci 13: 1984-1992.

Hartel DM, Schoenbaum EE, Selwyn PA, Kline J, Davenny K, Klein RS et al (1995). Heroin use during methadone maintenance treatment: the importance of methadone dose and cocaine use. Am J Public Health 85: 83-88.

Hepner IJ, Homewood J, Taylor AJ (2002). Methadone disrupts performance on the working memory version of the Morris water task. Physiol Behav 76: 41-49.

Hoffman DC (1989). The use of place conditioning in studying the neuropharmacology of drug reinforcement. Brain Res Bull 23: 373-387.

Ito R, Dalley JW, Howes SR, Robbins TW, Everitt BJ (2000). Dissociation in conditioned dopamine release in the nucleus accumbens core and shell in response to cocaine cues and during cocaine-seeking behavior in rats. J Neurosci 20: 7489-7495.

Ito R, Robbins TW, Everitt BJ (2004). Differential control over cocaine-seeking behavior by nucleus accumbens core and shell. Nat Neurosci 7: 389-397.

Kaddis FG, Uretsky NJ, Wallace LJ (1995). DNQX in the nucleus accumbens inhibits cocaine-induced conditioned place preference. Brain Res 697: 76-82.

Kidorf M, Stitzer ML (1993). Descriptive analysis of cocaine use of methadone patients. Drug Alcohol Depend 32: 267-275.

Kling MA, Carson RE, Borg L, Zametkin A, Matochik JA, Schluger J et al (2000). Opioid receptor imaging with positron emission tomography and [(18)F]cyclofoxy in long-term, methadonetreated former heroin addicts. J Pharmacol Exp Ther 295: 10701076.

Koob GF (1992). Drugs of abuse: anatomy, pharmacology and function of reward pathways. Trends Pharmacol Sci 13: 177-184.

Kosten TR, Rounsaville BJ, Kleber HD (1987). A 2.5-year follow-up of cocaine use among treated opioid addicts. Have our treatments helped? Arch Gen Psychiatry 44: 281-284.

Kosten TR, Rounsaville BJ, Kleber HD (1988). Antecedents and consequences of cocaine abuse among opioid addicts. A 2.5-year follow-up. J Nerv Ment Dis 176: 176-181.

Kreek MJ (2000). Methadone-related opioid agonist pharmacotherapy for heroin addiction. History, recent molecular and neurochemical research and future in mainstream medicine. Ann NY Acad Sci 909: 186-216.

Kreek MJ, LaForge KS, Butelman E (2002). Pharmacotherapy of addictions. Nat Rev Drug Discov 1: 710-726.

Leri F, Flores J, Rajabi H, Stewart J (2003). Effects of cocaine in rats exposed to heroin. Neuropsychopharmacology 28: 2102-2116.

Leri F, Franklin KB (2000). Effects of diazepam on conditioned place preference induced by morphine or amphetamine in the rat. Psychopharmacology 150: 351-360.

Leri F, Rizos Z (2005). Reconditioning of drug-related cues: a potential contributor to relapse after drug reexposure. Pharmacol Biochem Behav 80: 621-630.

Leri F, Tremblay A, Sorge RE, Stewart J (2004). Methadone maintenance reduces heroin- and cocaine-induced relapse without affecting stress-induced relapse in a rodent model of poly-drug use. Neuropsychopharmacology 29: 1312-1320.

Levin FR, Foltin RW, Fischman MW (1996). Pattern of cocaine use in methadone-maintained individuals applying for research studies. J Addict Dis 15: 97-106.

Magura S, Kan SY, Nwakeze PC, Demsky S (1998). Temporal patterns of heroin and cocaine use among methadone patients. Subst Use Misuse 33: 2441-2467.
Mansour A, Fox CA, Burke S, Meng F, Thompson RC, Akil H et al (1994). Mu, delta, and kappa opioid receptor mRNA expression in the rat CNS: an in situ hybridization study. J Comp Neurol 350: $412-438$.

Maxwell S, Shinderman M (1999). Optimizing response to methadone maintenance treatment: use of higher-dose methadone. J Psychoactive Drugs 31: 95-102.

McFarland K, Kalivas PW (2001). The circuitry mediating cocaineinduced reinstatement of drug-seeking behavior. J Neurosci 21: 8655-8663.

Moldow RL, Fischman AJ (1987). Cocaine induced secretion of ACTH, beta-endorphin, and corticosterone. Peptides 8: 819-822.

Mueller D, Perdikaris D, Stewart J (2002). Persistence and druginduced reinstatement of a morphine-induced conditioned place preference. Behav Brain Res 136: 389-397.

Mueller D, Stewart J (2000). Cocaine-induced conditioned place preference: reinstatement by priming injections of cocaine after extinction. Behav Brain Res 115: 39-47.

Negus SS, Mello NK (2004). Effects of chronic methadone treatment on cocaine- and food-maintained responding under second-order, progressive-ratio and concurrent-choice schedules in rhesus monkeys. Drug Alcohol Depend 74: 297-309.

Parker LA, Mcdonald RV (2000). Reinstatement of both a conditioned place preference and a conditioned place aversion with drug primes. Pharmacol Biochem Behav 66: 559-561.

Perez dlC, Trujols J, Ribalta E, Casas M (1997). Cocaine use immediately prior to entry in an inpatient heroin detoxification unit as a predictor of discharges against medical advice. $A m \mathrm{~J}$ Drug Alcohol Abuse 23: 267-279.

Preston KL, Sullivan JT, Strain EC, Bigelow GE (1996). Enhancement of cocaine's abuse liability in methadone maintenance patients. Psychopharmacology 123: 15-25.

Roth-Deri I, Schindler CJ, Yadid G (2004). A critical role for betaendorphin in cocaine-seeking behavior. Neuroreport 15: 519521.

Schluger JH, Borg L, Ho A, Kreek MJ (2001). Altered HPA axis responsivity to metyrapone testing in methadone maintained former heroin addicts with ongoing cocaine addiction. Neuropsychopharmacology 24: 568-575.

Schottenfeld RS, Chawarski MC, Pakes JR, Pantalon MV, Carroll KM, Kosten TR (2005). Methadone versus buprenorphine with contingency management or performance feedback for cocaine and opioid dependence. Am J Psychiatry 162: 340-349.

Self DW (2004). Regulation of drug-taking and -seeking behaviors by neuroadaptations in the mesolimbic dopamine system. Neuropharmacology 47(Suppl 1): 242-255.

Shaham Y, Erb S, Stewart J (2000). Stress-induced relapse to heroin and cocaine seeking in rats: a review. Brain Res Rev 33: 13-33.

Sigmon SC, Correia CJ, Stitzer ML (2004). Cocaine abstinence during methadone maintenance: effects of repeated brief exposure to voucher-based reinforcement. Exp Clin Psychopharmacol 12: 269-275.

Silverman K, Higgins ST, Brooner RK, Montoya ID, Cone EJ, Schuster CR et al (1996). Sustained cocaine abstinence in methadone maintenance patients through voucher-based reinforcement therapy. Arch Gen Psychiatry 53: 409-415.

Sinha R, Fuse T, Aubin LR, O'Malley SS (2000). Psychological stress, drug-related cues and cocaine craving. Psychopharmacology 152: 140-148.

Stine SM, Burns B, Kosten T (1991). Methadone dose for cocaine abuse. Am J Psychiatry 148: 1268.

Stine SM, Freeman MS, Burns B, Charney DS, Kosten TR (1992). The effects of methadone dose on cocaine abuse in a methadone program. Am J Addict 1: 294-303.

Strain EC, Stitzer ML, Liebson IA, Bigelow GE (1993). Doseresponse effects of methadone in the treatment of opioid dependence. Ann Intern Med 119: 23-27. 
Strain EC, Stitzer ML, Liebson IA, Bigelow GE (1994). Buprenorphine versus methadone in the treatment of opioid-dependent cocaine users. Psychopharmacology 116: 401-406.

Torres G, Rivier C (1992). Cocaine-induced stimulation of the rat hypothalamic-pituitary-adrenal axis is progressively attenuated following hourly-interval regimens of the drug. Life Sci 51: 10411048.

Unterwald EM (2001). Regulation of opioid receptors by cocaine. Ann NY Acad Sci 937: 74-92.

Unterwald EM, Horne-King J, Kreek MJ (1992). Chronic cocaine alters brain mu opioid receptors. Brain Res 584: 314-318.

Wang NS, Brown VL, Grabowski J, Meisch RA (2001). Reinforcement by orally delivered methadone, cocaine, and methadonecocaine combinations in rhesus monkeys: are the combinations better reinforcers? Psychopharmacology (Berl) 156: 63-72.

Wise RA (2004). Dopamine, learning and motivation. Nat Rev Neurosci 5: 483-494.

Yuferov V, Zhou Y, Spangler R, Maggos CE, Ho A, Kreek MJ (1999). Acute 'binge' cocaine increases mu-opioid receptor mRNA levels in areas of the rat mesolimbic mesocortical dopamine system. Brain Res Bull 48: 109-112.

Zangen A, Shalev U (2003). Nucleus accumbens beta-endorphin levels are not elevated by brain stimulation reward but do increase with extinction. Eur J Neurosci 17: 1067-1072.
Zhou Y, Spangler R, Maggos CE, LaForge KS, Ho A, Kreek MJ (1996). Steady-state methadone in rats does not change mRNA levels of corticotropin-releasing factor, its pituitary receptor or proopiomelanocortin. Eur J Pharmacol 315: 31-35.

Zhou Y, Spangler R, Maggos CE, Wan XM, Han JS, Ho A et al (1999). Hypothalamic-pituitary-adrenal activity and pro-opiomelanocortin mRNA levels in the hypothalamus and pituitary of the rat are differentially modulated by acute intermittent morphine with or without water restriction stress. J Endocrinol 163: 261-267.

Zhou Y, Spangler R, Schlussman SD, Ho A, Kreek MJ (2003). Alterations in hypothalamic-pituitary-adrenal axis activity and in levels of proopiomelanocortin and corticotropin-releasing hormone-receptor 1 mRNAs in the pituitary and hypothalamus of the rat during chronic 'binge' cocaine and withdrawal. Brain Res 964: 187-199.

Zhou Y, Yuferov V, Hofmann L, Bendor J, Ho A, Kreek MJ (2004). Withdrawal from chronic intermittent escalating-dose morphine increases mRNA levels of MOR in the hypothalamus and nucleus accumbens core and of vasopressin in the amygdala of the rat. NIDA Res Monogr Ser 185: 1.

Zubieta JK, Gorelick DA, Stauffer R, Ravert HT, Dannals RF, Frost JJ (1996). Increased mu opioid receptor binding detected by PET in cocaine-dependent men is associated with cocaine craving. Nat Med 2: 1225-1229. 